\title{
High-flow oxygen via tracheostomy facilitates weaning from prolonged mechanical ventilation in patients with restrictive pulmonary dysfunction: two case reports
}

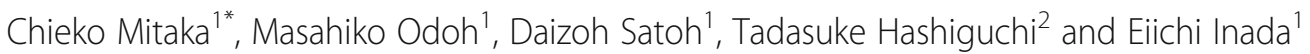

\begin{abstract}
Background: Weaning from prolonged mechanical ventilation is extremely difficult in tracheostomized patients with restrictive pulmonary dysfunction. High-flow oxygen via tracheostomy supplies heated and humidified oxygen gas at $>10 \mathrm{~L} /$ minute. However, little has been reported on the use of high-flow oxygen via tracheostomy during weaning from ventilators in patients with restrictive pulmonary dysfunction. We report successful weaning from ventilators in patients with restrictive pulmonary dysfunction using high-flow oxygen via tracheostomy.

Case presentation: The first patient is a 78-year-old Japanese man with severe pneumococcal pneumonia who was mechanically ventilated for more than 1 month after esophagectomy for esophageal cancer. After he underwent tracheostomy because of prolonged mechanical ventilation, restrictive pulmonary dysfunction appeared: tidal volume $230-240 \mathrm{~mL}$ and static compliance $14-15 \mathrm{~mL} / \mathrm{cmH}_{2} \mathrm{O}$ with $10 \mathrm{cmH}_{2} \mathrm{O}$ pressure support ventilation. He was weaned from the ventilator under inspiratory support with high-flow oxygen via tracheostomy over a period of 16 days (flow at $40 \mathrm{~L} /$ minute and fraction of inspired oxygen of 0.25 ). The second patient is a 69-year-old Japanese man who developed aspiration pneumonia after esophagectomy and received prolonged mechanical ventilation via tracheostomy. He developed restrictive pulmonary dysfunction. High-flow oxygen via tracheostomy (flow at $40 \mathrm{~L} /$ minute with fraction of inspired oxygen of 0.25 ) was administered with measurement of the airway pressure and at the entrance of the tracheostomy tube. The measured values were as follows: $0.21-0.3 \mathrm{cmH}_{2} \mathrm{O}, 0.21-0.56$ $\mathrm{cmH}_{2} \mathrm{O}, 0.54-0.91 \mathrm{cmH}_{2} \mathrm{O}, 0.76-2.01 \mathrm{cmH}_{2} \mathrm{O}, 1.17-2.01 \mathrm{cmH}_{2} \mathrm{O}$, and 1.76-2.01 $\mathrm{cmH}_{2} \mathrm{O}$ at $10 \mathrm{~L} /$ minute, $20 \mathrm{~L} /$ minute, $30 \mathrm{~L} /$ minute, $40 \mathrm{~L} /$ minute, $50 \mathrm{~L} /$ minute, and $60 \mathrm{~L} /$ minute, respectively. The airway pressures were continuously positive and did not become negative even during inspiration, suggesting that high-flow oxygen via tracheostomy reduces inspiratory effort. He was weaned from the ventilator under inspiratory support with high-flow oxygen via tracheostomy over a period of 12 days.
\end{abstract}

Conclusions: High-flow oxygen via tracheostomy may reduce the inspiratory effort and enhance tidal volume by delivering high-flow oxygen and facilitate weaning from prolonged mechanical ventilation in patients with restrictive pulmonary dysfunction.

Keywords: High-flow oxygen, Hypercapnia, Restrictive pulmonary dysfunction, Tracheostomy, Weaning

\footnotetext{
*Correspondence: c-mitaka@juntendo.ac.jp

'Department of Anesthesiology and Pain Medicine, Juntendo University,

2-1-1, Hongo, Bunkyo-ku, Tokyo 113-8421, Japan

Full list of author information is available at the end of the article
}

(c) The Author(s). 2018 Open Access This article is distributed under the terms of the Creative Commons Attribution 4.0 International License (http://creativecommons.org/licenses/by/4.0/), which permits unrestricted use, distribution, and reproduction in any medium, provided you give appropriate credit to the original author(s) and the source, provide a link to the Creative Commons license, and indicate if changes were made. The Creative Commons Public Domain Dedication waiver (http://creativecommons.org/publicdomain/zero/1.0/) applies to the data made available in this article, unless otherwise stated. 


\section{Background}

Weaning from prolonged mechanical ventilation is extremely difficult in tracheostomized patients with restrictive pulmonary dysfunction. Mechanical ventilation for longer than 21 days is associated with increased mortality, health care utilization, and health care costs in critically ill patients [1]. High-flow oxygen via tracheostomy (HFT) delivered by Optiflow ${ }^{\mathrm{TM}}$ (OPT 870; Fisher \& Paykel Healthcare Ltd, Auckland, New Zealand) is a method to supply heated and humidified oxygen gas at $>10 \mathrm{~L} /$ minute. Although high-flow oxygen through nasal cannula (HFNC) has demonstrated clinical benefits, such as improved oxygenation [2] and reduced 90-day mortality [3], the mechanisms of HFT may differ from those of HFNC. Furthermore, minimal information has been reported on the use of HFT during weaning from ventilators in patients with restrictive pulmonary dysfunction. Our hypothesis is that HFT increases tidal volume by reducing inspiratory effort in patients with restrictive pulmonary dysfunction. Here, we report two cases in which respiratory support with HFT proved useful for weaning from prolonged mechanical ventilation in patients with restrictive pulmonary dysfunction.

\section{Case presentation}

\section{Case 1}

A 78-year-old (height $163.3 \mathrm{~cm}$, weight $61.3 \mathrm{~kg}$ ) Japanese man was admitted to our intensive care unit (ICU) after esophagectomy with gastric reconstruction for esophageal cancer. His body temperature was $36.9{ }^{\circ} \mathrm{C}$ and heart rate was 96 beats/minute. His blood pressure was 148/ $68 \mathrm{mmHg}$ on ICU admission. Physical and neurological examinations were not significant. His past medical history included appendectomy (8 years of age) and lumber canal stenosis (70 years of age). He did not smoke cigarettes but drank Japanese alcohol (360 ml/day). Regarding family history, his elder brother died of esophageal cancer.

On ICU day 5, he developed new onset fever up to $38.0{ }^{\circ} \mathrm{C}$, increase in sputum, and hypoxemia with $90 \%$ arterial oxygen saturation by pulse oximetry $\left(\mathrm{SpO}_{2}\right)$ with mask oxygen at $10 \mathrm{~L} /$ minute with bilateral pulmonary coarse crackles. Therefore, he was intubated. A chest X-ray revealed diffuse bilateral pulmonary infiltrates predominantly in his right lung with pleural effusion (Fig. 1). Laboratory findings revealed white blood cell count $5.7 \times 10^{9} / \mathrm{L}$, red blood cell count $2.25 \times 10^{12} / \mathrm{L}$, hemoglobin $7.3 \mathrm{~g} / \mathrm{dL}$, hematocrit $21.4 \%$, platelet $145 \times 10^{9} / \mathrm{L}$, aspartate aminotransferase $54 \mathrm{U} / \mathrm{L}$, alanine aminotransferase $55 \mathrm{U} / \mathrm{L}$, total bilirubin $4.11 \mathrm{mg} / \mathrm{dL}$, albumin $2.2 \mathrm{~g} / \mathrm{dL}$, urea nitrogen $38 \mathrm{mg} / \mathrm{dL}$, creatinine $0.83 \mathrm{mg} / \mathrm{dL}$, C-reactive protein $18.7 \mathrm{mg} / \mathrm{dL}$, and urinary creatinine $95 \mathrm{mg} / \mathrm{dL}$ after intubation. Because sputum culture revealed Streptococcus pneumoniae on ICU day 7, the antibiotic was changed from cefmetazole to meropenem.

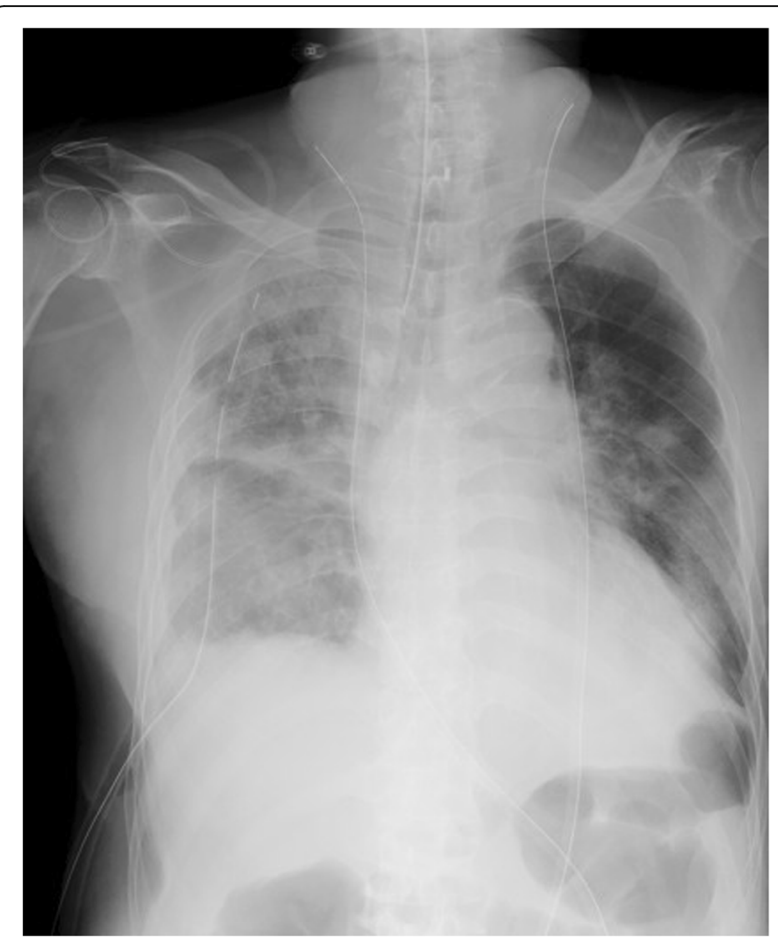

Fig. 1 Chest X-ray depicting diffuse bilateral pulmonary infiltrates predominantly in the right lung with pleural effusion after tracheal intubation on intensive care unit day 5

He underwent a long period of mechanical ventilation, ultimately undergoing tracheostomy on ICU day 38. Although his oxygenation was good with partial pressure of arterial oxygen/fraction of inspired oxygen $\left(\mathrm{PaO}_{2} / \mathrm{F}_{\mathrm{I}} \mathrm{O}_{2}\right)>300 \mathrm{mmHg}$, restrictive pulmonary dysfunction developed: tidal volume $230-240 \mathrm{~mL}$, static compliance $14-15 \mathrm{~mL} / \mathrm{cmH}_{2} \mathrm{O}$ with $10 \mathrm{cmH}_{2} \mathrm{O}$ pressure support ventilation, respiratory rate 34 beats/minute, and partial pressure of arterial carbon dioxide $\left(\mathrm{PaCO}_{2}\right) 46 \mathrm{mmHg}$. We tried to wean him from mechanical ventilation with support by HFT setting the flow at $40 \mathrm{~L} /$ minute with $\mathrm{F}_{\mathrm{I}} \mathrm{O}_{2}$ of 0.25 because the maximum inspiratory flow of the ventilator was $40 \mathrm{~L} /$ minute during $10 \mathrm{cmH}_{2} \mathrm{O}$ pressure support ventilation. By setting the flow at the same rate as the ventilator, we hoped to reduce his inspiratory effort. HFT was used in the daytime, and a ventilator with $5 \mathrm{cmH}_{2} \mathrm{O}$ pressure support with $5 \mathrm{cmH}_{2} \mathrm{O}$ positive end-expiratory pressure (PEEP) was used at night for the first 8 days. In the next 8 days, HFT was used around the clock. Table 1 presents the respiratory parameters during HFT. Under respiratory support with HFT, his condition was stable, and his physiotherapy rehabilitation continued uneventfully. The HFT optimally delivered humidified gas, which improved the thinning of his bronchial secretions. He was discharged from the ICU to the general ward on ICU day 127 . His physiotherapy rehabilitation continued for 
Table 1 Changes in respiratory parameters during high-flow oxygen via tracheostomy in Case 1

\begin{tabular}{|c|c|c|c|c|c|c|c|c|c|c|c|c|c|c|c|c|}
\hline HFT day & 1 & 2 & 3 & 4 & 5 & 6 & 7 & 8 & 9 & 10 & 11 & 12 & 13 & 14 & 15 & 16 \\
\hline \multicolumn{17}{|l|}{ HFT setting } \\
\hline $\mathrm{F}_{1} \mathrm{O}_{2}$ & 0.25 & 0.25 & 0.25 & 0.25 & 0.25 & 0.25 & 0.25 & 0.25 & 0.25 & 0.25 & 0.25 & 0.25 & 0.25 & 0.25 & 0.25 & 0.25 \\
\hline Flow (L/minute) & 40 & 40 & 40 & 40 & 40 & 40 & 40 & 20 & 15 & 15 & 15 & 15 & 15 & 15 & 15 & 15 \\
\hline RR (breaths/minute) & 40 & 30 & 35 & 37 & 26 & 30 & 35 & 36 & 35 & 27 & 29 & 26 & 22 & 20 & 22 & 21 \\
\hline $\mathrm{SpO}_{2}(\%)$ & 97 & 98 & 97 & 97 & 96 & 98 & 97 & 98 & 96 & 96 & 96 & 96 & 98 & 95 & 98 & 96 \\
\hline $\mathrm{etCO}_{2}(\mathrm{mmHg})$ & 47 & 41 & 40 & 39 & 42 & 42 & 40 & 41 & 39 & 35 & 34 & 35 & 37 & 35 & 38 & 41 \\
\hline $\mathrm{V}_{\mathrm{T}}(\mathrm{mL})$ & & & & 240 & & & & 260 & & & 300 & & & 300 & & \\
\hline \multicolumn{17}{|l|}{ Arterial blood gases } \\
\hline $\mathrm{pH}$ & & & & 7.46 & & & & & & & 7.47 & & & & & \\
\hline $\mathrm{PaCO}_{2}(\mathrm{mmHg})$ & & & & 47 & & & & & & & 44 & & & & & \\
\hline $\mathrm{PaO}_{2}(\mathrm{mmHg})$ & & & & 92 & & & & & & & 87 & & & & & \\
\hline $\mathrm{HCO}_{3}^{-}(\mathrm{mmol} / \mathrm{L})$ & & & & 32.5 & & & & & & & 31.2 & & & & & \\
\hline
\end{tabular}

Abbreviations: et $\mathrm{CO}_{2}$ end-tidal carbon dioxide, $\mathrm{F}_{1} \mathrm{O}_{2}$ fraction of inspired oxygen, $\mathrm{HFT}$ high-flow oxygen via tracheostomy, $\mathrm{HCO}_{3}{ }^{-}$bicarbonate ion, $\mathrm{PaCO}_{2}$ partial pressure of arterial carbon dioxide, $\mathrm{PaO}_{2}$ partial pressure of arterial oxygen, $R R$ respiratory rate, $\mathrm{SpO}_{2}$ arterial oxygen saturation by pulse oximetry, $V_{T}$ tidal volume (measured by Wright respirometer)

2 months, and he was transferred to a rehabilitation hospital on day 201 of hospitalization.

\section{Case 2}

A 69-year-old (height $160.0 \mathrm{~cm}$, weight $37.1 \mathrm{~kg}$ ) Japanese man was admitted to our ICU from the emergency room due to severe dyspnea. His past medical history included extracorporeal shock wave lithotripsy due to urinary calculus (56 years of age), endoscopic colon polypectomy because of colon polyps (66 years of age), and esophagectomy with gastric reconstruction for esophageal cancer after a stint of preoperative chemoradiation therapy (66 years of age). He smoked 30 cigarettes/day for 40 years and drank whisky (1 bottle/4 days). He was not on any medication. Regarding family history, his grandmother died of liver cancer. On physical examination, he was confused and restless, and his breathing was shallow with reduced air entry to both lungs. A neurological examination was not significant. His vital signs were as follows: heart rate 122 beats/minute, blood pressure $80 /$ $58 \mathrm{mmHg}$, respiratory rate 26 breaths/minute, and temperature $38.7{ }^{\circ} \mathrm{C}$. Arterial blood gases exhibited respiratory acidosis: $\mathrm{pH}$ 7.21, $\mathrm{PaCO}_{2} 117 \mathrm{mmHg}, \mathrm{PaO}_{2}$ $76 \mathrm{mmHg}$, and bicarbonate ion $\left(\mathrm{HCO}_{3}{ }^{-}\right) 45.9 \mathrm{mmol} / \mathrm{L}$ with mask oxygen at $6 \mathrm{~L} /$ minute. Even bag-valve-mask ventilation could not provide proper ventilation. He was immediately intubated, and numerous food particles, such as beans and rice, were aspirated from his trachea. Therefore, we removed these food particles by bronchoscope as soon as possible. A chest X-ray revealed diffuse bilateral pulmonary infiltrates (Fig. 2). He was diagnosed as having aspiration pneumonia and placed on mechanical ventilation. Laboratory findings revealed white blood cell count $0.9 \times 10^{9} / \mathrm{L}$, red blood cell count $4.66 \times 10^{12} / \mathrm{L}$, hemoglobin $12.1 \mathrm{~g} / \mathrm{dL}$, hematocrit $41.0 \%$, platelet $297 \times 10^{9} / \mathrm{L}$, aspartate aminotransferase $17 \mathrm{U} / \mathrm{L}$, alanine aminotransferase $7 \mathrm{U} / \mathrm{L}$, total bilirubin $0.59 \mathrm{mg} / \mathrm{dL}$, albu$\min 2.2 \mathrm{~g} / \mathrm{dL}$, urea nitrogen $26 \mathrm{mg} / \mathrm{dL}$, creatinine $0.75 \mathrm{mg} / \mathrm{dL}$, and C-reactive protein $1.7 \mathrm{mg} / \mathrm{dL}$ on ICU admission.

He underwent tracheostomy on ICU day 32 due to prolonged mechanical ventilation. Although his

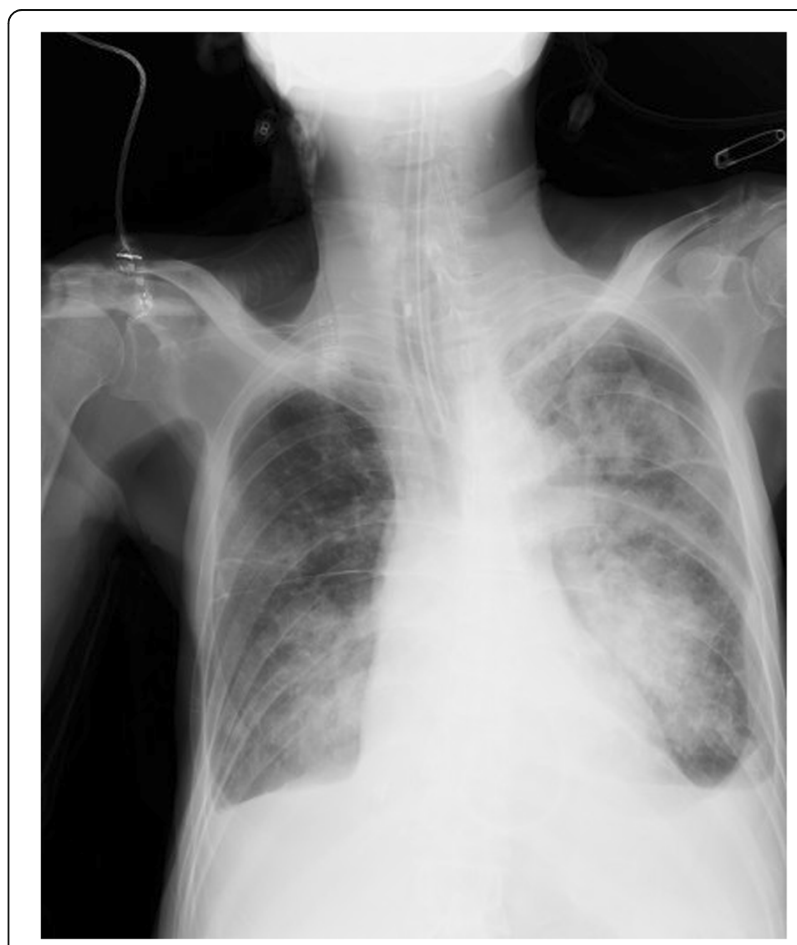

Fig. 2 Chest X-ray depicting diffuse bilateral pulmonary infiltrates after tracheal intubation on intensive care unit day 1 
oxygenation was good $\left(\mathrm{PaO}_{2} / \mathrm{F}_{\mathrm{I}} \mathrm{O}_{2}>300 \mathrm{mmHg}\right)$, he had restrictive pulmonary dysfunction: tidal volume 210-220 mL, static compliance $16-17 \mathrm{~mL} / \mathrm{cmH}_{2} \mathrm{O}$ with $10 \mathrm{cmH}_{2} \mathrm{O}$ pressure support ventilation, respiratory rate 30 beats/minute and $\mathrm{PaCO}_{2} 46 \mathrm{mmHg}$. We tried to wean him from mechanical ventilation with support by HFT (flow at $40 \mathrm{~L} /$ minute with $\mathrm{F}_{\mathrm{I}} \mathrm{O}_{2}$ of 0.25 ). Table 2 presents the respiratory parameters over the 4-day period HFT was administered. On HFT day 4, his arterial blood gases were $\mathrm{pH} 7.41, \mathrm{PaCO}_{2} 58 \mathrm{mmHg}, \mathrm{PaO}_{2} 68 \mathrm{mmHg}$, and $\mathrm{HCO}_{3}{ }^{-} 35.7 \mathrm{mmol} / \mathrm{L}$. Judging his condition as satisfactory, we switched from HFT to a $3 \mathrm{~L} /$ minute oxygen T-piece. One hour after the T-piece was commenced, he complained of dyspnea and his arterial blood gases moderately worsened $\left(\mathrm{pH} 7.34, \mathrm{PaCO}_{2} 72 \mathrm{mmHg}, \mathrm{PaO}_{2}\right.$ $106 \mathrm{mmHg}$, and $\mathrm{HCO}_{3}{ }^{-} 37.3 \mathrm{mmol} / \mathrm{L}$ ). At that time, his tidal volume was $200 \mathrm{~mL}$. We decided to switch back to HFT (flow at $40 \mathrm{~L} /$ minute with $\mathrm{F}_{\mathrm{I}} \mathrm{O}_{2}$ of 0.25 ), and his arterial blood gases improved 1 hour later: $\mathrm{pH}$ 7.40, $\mathrm{PaCO}_{2}$ $60 \mathrm{mmHg}, \mathrm{PaO}_{2} 71 \mathrm{mmHg}$, and $\mathrm{HCO}_{3}{ }^{-} 35.9 \mathrm{mmol} / \mathrm{L}$. On HFT day 5, his $\mathrm{PaCO}_{2}$ increased to $70 \mathrm{mmHg}$. This condition suggested respiratory muscle fatigue; however, no complaints of dyspnea were noted. We decided to apply the HFT at daytime and switch to a ventilator (10 $\mathrm{cmH}_{2} \mathrm{O}$ pressure support with $5 \mathrm{cmH}_{2} \mathrm{O}$ PEEP) at night, and the treatment regimen was continued accordingly for the next 8 days.

We evaluated tracheal pressure during HFT using a flow analyzer (CITREX ${ }^{\circ}$, TOKIBO, Co. Ltd, Tokyo, Japan) to measure airway pressure and at the entrance of the tracheostomy tube. The measured values were as follows: 0.21- $0.3 \mathrm{cmH}_{2} \mathrm{O}, 0.21-0.56 \mathrm{cmH}_{2} \mathrm{O}, 0.54-0.91 \mathrm{cmH}_{2} \mathrm{O}$, 0.76-2.01 $\mathrm{cmH}_{2} \mathrm{O}, 1.17-2.01 \mathrm{cmH}_{2} \mathrm{O}$, and 1.76-2.01 $\mathrm{cmH}_{2} \mathrm{O}$ at $10 \mathrm{~L} /$ minute, $20 \mathrm{~L} /$ minute, $30 \mathrm{~L} /$ minute,
$40 \mathrm{~L} /$ minute, $50 \mathrm{~L} /$ minute, and $60 \mathrm{~L} /$ minute, respectively. The airway pressure was continuously positive and did not become negative even during inspiration. These results suggest that HFT reduces inspiratory effort. Under respiratory support with HFT and physiotherapy rehabilitation, our patient was successfully weaned from the ventilator. He was discharged from the ICU to the general ward on ICU day 51. His physiotherapy rehabilitation continued for 1 month. He was discharged to home on day 86 of hospitalization and returned for a follow-up visit.

\section{Discussion}

To the best of our knowledge, this report describes the first attempt to administer HFT support during weaning from prolonged mechanical ventilation in patients with restrictive pulmonary dysfunction. Our data suggest that HFT was useful for ventilator weaning. The two patients we weaned from mechanical ventilation exhibited distinctive restriction of the respiratory muscles. HFT increased alveolar ventilation by increasing tidal volume, resulting in reduced respiratory rate and $\mathrm{PaCO}_{2}$. Support of inspiration by HFT may also be beneficial for patients who have low tidal volume due to tachypnea or rapid shallow breathing. In our second patient, $\mathrm{PaCO}_{2}$ increased from 58 to $72 \mathrm{mmHg}$ after switching from HFT to a T-piece. Then, $\mathrm{PaCO}_{2}$ returned to the previous level after switching back to HFT. Even a small reduction of inspiratory effort was expected to cause an increase in the tidal volume as the flow of the HFT was set to the same flow as the ventilator. We think that the main mechanisms of HFT involve reduction of inspiratory effort and increase in tidal volume in patients with restrictive pulmonary dysfunction. As a result, the work of breathing was expected to decrease due to the patient's

Table 2 Changes in respiratory parameters during high-flow oxygen via tracheostomy in Case 2

\begin{tabular}{|c|c|c|c|c|c|c|c|c|c|c|c|c|}
\hline HFT day & 1 & 2 & 3 & 4 & 5 & 6 & 7 & 8 & 9 & 10 & 11 & 12 \\
\hline \multicolumn{13}{|l|}{ HFT setting } \\
\hline $\mathrm{F}_{1} \mathrm{O}_{2}$ & 0.3 & 0.25 & 0.25 & 0.25 & 0.3 & 0.3 & 0.3 & 0.3 & 0.3 & 0.3 & 0.3 & 0.3 \\
\hline Flow (L/minute) & 40 & 40 & 40 & 40 & 40 & 50 & 40 & 40 & 40 & 40 & 30 & 20 \\
\hline RR (breaths/minute) & 39 & 22 & 26 & 24 & 24 & 31 & 32 & 30 & 30 & 23 & 26 & 20 \\
\hline $\mathrm{SpO}_{2}(\%)$ & 96 & 94 & 95 & 94 & 95 & 96 & 97 & 97 & 98 & 98 & 99 & 100 \\
\hline $\mathrm{etCO}_{2}(\mathrm{mmHg})$ & 44 & 37 & 40 & 42 & 46 & 48 & 46 & 49 & 48 & 45 & 43 & 46 \\
\hline $\mathrm{V}_{\mathrm{T}}(\mathrm{mL})$ & & & & 220 & 210 & 210 & 230 & 220 & 220 & 230 & 230 & 230 \\
\hline \multicolumn{13}{|l|}{ Arterial blood gases } \\
\hline $\mathrm{pH}$ & & 7.47 & 7.43 & 7.41 & 7.37 & 7.40 & 7.38 & 7.39 & 7.42 & 7.42 & 7.42 & 7.42 \\
\hline $\mathrm{PaCO}_{2}(\mathrm{mmHg})$ & & 50 & 53 & 58 & 68 & 66 & 70 & 66 & 61 & 59 & 59 & 60 \\
\hline $\mathrm{PaO}_{2}(\mathrm{mmHg})$ & & 61 & 73 & 68 & 77 & 80 & 86 & 79 & 91 & 93 & 72 & 85 \\
\hline $\mathrm{HCO}_{3}^{-}(\mathrm{mmol} / \mathrm{L})$ & & 53.1 & 34.7 & 35.9 & 38.5 & 40.1 & 40.1 & 38.8 & 39.1 & 37.9 & 36.9 & 37.8 \\
\hline
\end{tabular}

Abbreviations: et $\mathrm{CO}_{2}$ end-tidal carbon dioxide, $\mathrm{F}_{1} \mathrm{O}_{2}$ fraction of inspiratory oxygen, $\mathrm{HFT}$ high-flow oxygen via tracheostomy, $\mathrm{HCO}_{3}{ }^{-}$bicarbonate ion, $\mathrm{PaCO}_{2}$ partial pressure of arterial carbon dioxide, $\mathrm{PaO}_{2}$ partial pressure of arterial oxygen, $R R$ respiratory rate, $\mathrm{SpO}_{2}$ arterial oxygen saturation by pulse oximetry, $V_{T}$ tidal volume (measured by Wright respirometer) 
slower and deeper breathing. HFT may support inspiration by delivering a high flow and play an important role in decreasing the work of breathing in patients with restrictive pulmonary dysfunction. In a randomized crossover comparison between HFT and T-piece by Corley et al. [4], the mean airway pressure during HFT was significantly increased compared with the T-piece 15 minutes after HFT initiation. However, their data revealed no significant difference in end-expiratory lung volume (EELV) between HFT and the T-piece. In contrast to our cases, their patients lacked restrictive pulmonary dysfunction. The absence of dysfunction in these patients might explain the similar EELV values measured with HFT and a T-piece. In our cases, $\mathrm{PaCO}_{2}$ and respiratory rate were gradually reduced during HFT, whereas tidal volume gradually increased.

HFNC clears the upper airways of expired air and reduces dead space [5, 6] while concomitantly reducing the work of breathing and $\mathrm{PaCO}_{2}$ levels [7]. However, the HFT system results in a more open circuit during inspiration and expiration compared with HFNC. However, this case report demonstrated that HFT increased tidal volume by reducing inspiratory effort in patients with restrictive pulmonary dysfunction.

\section{Conclusions}

The use of HFT was effective for weaning from prolonged mechanical ventilation in patients with restrictive pulmonary dysfunction. HFT may reduce the inspiratory effort and enhance tidal volume by delivering high-flow oxygen and facilitate weaning from ventilators in these patients. We recommend that the first setting of HFT flow is the same as the maximum inspiratory flow of the ventilator during pressure support ventilation, and the duration of HFT is gradually extended in combination with physiotherapy rehabilitation. Further studies are needed to elucidate the efficacy of HFT during weaning from prolonged mechanical ventilation in a larger population of patients with restrictive pulmonary dysfunction.

\section{Abbreviations}

EELV: End-expiratory lung volume; $\mathrm{F}_{1} \mathrm{O}_{2}$ : Fraction of inspired oxygen $\mathrm{HCO}_{3}^{-}$: Bicarbonate ion; HFNC: High-flow oxygen through nasal cannula; HFT: High-flow oxygen via tracheostomy; ICU: Intensive care unit; $\mathrm{PaCO}_{2}:$ Partial pressure of arterial carbon dioxide; $\mathrm{PaO}_{2}:$ Partial pressure of arterial oxygen; PEEP: Positive end-expiratory pressure

\section{Acknowledgements}

We thank Nature Research Editing Service (http://bit.ly/NRES-HS) for English language editing.

\section{Availability of data and materials}

The datasets used and/or analyzed during the current study are available from the corresponding author on reasonable request.

\section{Authors' contributions}

CM coordinated the study and was a major contributor to manuscript writing. MO and TH were responsible for patient care and data collection. DS and El contributed to data interpretation. All authors read and approved the final manuscript.
Ethics approval and consent to participate

Not applicable.

\section{Consent for publication}

Written informed consent was obtained from the patients for publication of this case report and any accompanying images. A copy of the written consent is available for review by the Editor-in-Chief of this journal.

\section{Competing interests}

The authors declare that they have no competing interests.

\section{Publisher's Note}

Springer Nature remains neutral with regard to jurisdictional claims in published maps and institutional affiliations.

\section{Author details}

'Department of Anesthesiology and Pain Medicine, Juntendo University, 2-1-1, Hongo, Bunkyo-ku, Tokyo 113-8421, Japan. ${ }^{2}$ Department of Esophageal and Gastroenterological Surgery, Juntendo University, Tokyo, Japan.

Received: 17 April 2018 Accepted: 3 September 2018

Published online: 12 October 2018

\section{References}

1. Hill AD, Fowler RA, Burns KEA, Rose L, Pint RL, Scales DC. Long-term outcomes and health care utilization after prolonged mechanical ventilation. Ann Am Thorac Soc. 2017;14:355-62.

2. Maggiore SM, Idone FA, Vaschetto R, Festa R, Cataldo A, Antonicelli F, Montini L, De Gaetano A, Navalesi P, Antonell M. Nasal high-flow versus Venturi mask oxygen therapy after extubation. Effects on oxygenation, comfort, and clinical outcome. Am J Respir Crit Care Med. 2014;190:282-8.

3. Frat JP, Thille AW, Mercat A, Girault C, Ragot S, Perbet S, Prat G, Boulain T, Morawiec E, Cottereau A, Devaquet J, Nseir S, Razazi K, Mira JP, Argaud L, Chakarian JC, Richard JD, Wittebole X, Chevalier S, Herbland A, Fartoukh M, Constantin JM, Tonnelier JM, Pierrot M, Mathonnet A, Béduneau G, Delétage-Métreau C, JCM Richard, Brochard L, Robert R, for the FLORALI Study Group and the REVA Network. High-flow oxygen through nasal cannula in acute hypoxemic respiratory failure. N Engl J Med. 2015;372: 2185-96.

4. Corley A, Edwards M, Spooner AJ, Dunster KR, Anstey C, Fraser JF. High-flow oxygen via tracheostomy improves oxygenation in patients weaning from mechanical ventilation: a randomized crossover study. Intensive Care Med. 2017:43:465-7.

5. Fricke K, Tatkov S, Domanski U, Franke K, Nilius G, Schneider H. Case report. Nasal high flow reduces hypercapnia by clearance of anatomical dead space in a COPD patient. Respir Med Case Rep. 2016;19:115-7. Published online 2016 Aug 26. https://doi.org/10.1016/j.rmcr.2016.08.010.

6. Möller W, Feng S, Domanski U, Franke KJ, Celik G, Bartenstein P, Becker S, Meyer G, Schmid O, Eickelberg O, Tatkov S, Nilius G. Nasal high flow reduces dead space. J Appl Physiol. 2017;122:191-7.

7. Biselli PJC, Kirkness JP, Grote L, Fricke K, Schwartz AR, Smith P, Schneider H. Nasal high-flow therapy reduces work of breathing compared with oxygen during sleep in COPD and smoking controls: a prospective observational study. J Appl Physiol. 2017;122:82-8.

\section{Ready to submit your research? Choose BMC and benefit from}

- fast, convenient online submission

- thorough peer review by experienced researchers in your field

- rapid publication on acceptance

- support for research data, including large and complex data types

- gold Open Access which fosters wider collaboration and increased citations

- maximum visibility for your research: over 100M website views per year

At BMC, research is always in progress.

Learn more biomedcentral.com/submissions 